\title{
固体高分子型燃料電池用炭素被覆ステンレス製 セパレータの開発とその発電特性
}

\begin{tabular}{|c|c|c|}
\hline & 陽 -2 & 橋 本 \\
\hline 棚 瀬 繁 雄3 & 青井芳 史 ${ }^{2}$ & 岩佐美喜男 ${ }^{3}$ \\
\hline
\end{tabular}

1株式会社栗本鐵工所技術開発本部研究開発部

2 龍谷大学理工学部物質化学科

3 産業技術総合研究所ユビキタスエネルギー研究部門

J. Japan Inst. Metals, Vol. 71, No. 7 (2007), pp. 545-552

(C) 2007 The Japan Institute of Metals

\section{Development of Carbon Coated Stainless Separators and Their Polarization Performance for Polymer Electrolyte Fuel Cell}

Masami Ueda ${ }^{1}$, Yoichi Mori², Masaru Hashimotoํㅜㄹ Shigeki Yamamuro ${ }^{1}$, Shigeo Tanase ${ }^{3}$, Yoshifumi Aoi ${ }^{2}$, Mikio Iwasa ${ }^{3}$ and Tetsuo Sakai ${ }^{3}$

${ }^{1} R \&$ D Dept., Technology Development Bureau, KURIMOTO, Ltd., Osaka 559-0021

${ }^{2}$ Faculty of Science and Technology, Ryukoku University, Otsu 520-2194

${ }^{3}$ National Institute of Advanced Industrial Science and Technology (AIST), Research Institute for Ubiquitous Energy Devices, Ikeda $563-8577$

Conductive amorphous carbon was coated on the stainless steel separators by using electron cyclotron resonance (ECR) plasma sputtering technique. The carbon-coating reduced contact resistance between carbon paper and stainless steel substrate by two orders of magnitude. The carbon-coating also enhanced corrosion resistance of the stainless steels. Polarization performances of the polymer electrolyte fuel Cell (PEFC) using the carbon-coated SUS316L and SUS329J4L separators were comparable with that using the conventional carbon separator.

(Received February 19, 2007; Accepted April 4, 2007)

Keywords: polymer electrolyte fuel cell, stainless separator, electron cyclotron resonance plasma sputtering, X-ray photoelectron spectroscopy; radio frequency glow discharge plasmas-optical emission spectrometer

\section{1. 緒言}

固体高分子型然料電池 (PEFC) は, 水素等の燃料の化学工 ネルギーを電気エネルギーに変換する効率が高く, 出力密度 が大きい. また, 室温付近で動作するため電池の起動・停止 が容易であることから, 家庭用, 自動車用等の電源として精 力的に開発が進められている. PEFC が高効率で低温作動が 可能な所以は, 電解質膜に用いられているパーフルオロスル フォロ酸膜が水溶液と同じ程度の温度で作動する, 水の存在 下でプロトン導電性を示し比較的イオン導電率が高い, 薄膜 にすることができる, ガスの差圧に耐えるなどの特徵を有し ているからである1). その電池は電極一電解質積層体 (membrane electrode assembly, MEA), セパレータなどからなる が, 電解質膜が強い酸性を示すので, 現在, 導電性抢よび耐 食性の観点からセパレータには, カーボン系材料(黒鉛など) が主に使われている。しかし，このカーボン系セパレータ は, 燃料である水素や酸化剤である空気のクロスオーバを避 け, かつ, セル(単電池)やスタック(積層電池)に打ける機械
的な強度を確保するため， $2 \mathrm{~mm}$ 程度の厚さが必要とな る. そのため, セルやスタックの大型化が避けられず, 実用 上のネックとなっている.

このような中で, セパレータの薄肉化 $(\sim 0.2 \mathrm{~mm})$ および 強度の向上が可能な金属系セパレータの開発が期待されてい るが，PEFCに求められる耐食性を満足する材料では，その 表面に不働態皮膜を形成し, 接触抵抗が大きくなる傾向があ り，これを改善するための多くの提案がある.たとえば，導 電性金属析出物を鋼板表面に突出させて “不働態皮膜を貫通 する電気の通り道”を作ったステンレス鋼 ${ }^{2}$, ステンレスの チタンクラッド材に導電性塗料を塗布した材料3)などが, 報 告されている.

著者らは，これまで安価で耐食性に優れる市販ステンレス 材料を選定して, これに適当な表面導電性処理を施し, 燃料 電池セパレータに利用することを検討してきた．その中で， ステンレス表面を炭素で被覆することで, 従来のカーボン系 セパレータと同等の燃料電池性能が得られることを見いだし た ${ }^{4)}$.

本研究では, 耐食性の異なる 3 種類の市販ステンレス鋼 
について，炭素被覆処理が耐食性および導電性，発電特性に 及ぼす影響について詳細に検討したので，報告する。

\section{2. 実 験 方 法}

\section{1 供試材}

供試材には，JIS 規格品の中で汎用性があり耐食性が異な るステンレス鋼として，1) 最も一般的なステンレスで 18-8 ステンレスとも呼ばれる SUS304，2)SUS304 よりも耐孔食 性や耐粒界腐食性に優れる SUS316L，3)耐酸性や耐孔食性 に優れる SUS329J4L を, 選定して用いた。供試材の成分分 析值を Table 1 に示す。

\section{2 導電性炭素膜成膜方法}

導電性炭素膜の成膜は，電子サイクロトロン共鳴 (electron cyclotron resonance, ECR) スパッタリング法によって 行った。本実験に用いた ECR スパッタリング装置の概略図 を Fig. 1 に示す。この ECR スパッタリング装置はプラズマ 室と成膜室とからなる．プラズマ室では $2.45 \mathrm{GHz}$ の電磁波 を上部から電磁コイルに印加すると共に，875 ガウスの磁場 を電磁コイル中央部付近に発生させる．この条件で電子サイ クロトロン共鳴が生じ，プラズマ室で発生したプラズマは磁 場勾配により成膜室内に運ばれ基板表面に照射される。 た，プラズマ室で発生したプラズマはプラズマ室に設置され た円筒状のターゲットに衝突しスパッタリングが生じる。こ のため, スパッタリングされたターゲット材料(カーボン)も

Table 1 Chemical composition of stainless steels for test specimen in mass $\%$.

\begin{tabular}{lccccccccc}
\hline \multicolumn{1}{c}{ Specimen } & $\mathrm{C}$ & $\mathrm{Si}$ & $\mathrm{Mn}$ & $\mathrm{P}$ & $\mathrm{S}$ & $\mathrm{Ni}$ & $\mathrm{Cr}$ & $\mathrm{Mo}$ & $\mathrm{N}$ \\
\hline SUS304 & 0.04 & 0.38 & 1.29 & 0.027 & 0.002 & 8.17 & 18.38 & - & - \\
\hline SUS316L & 0.01 & 0.36 & 0.95 & 0.021 & 0.001 & 12.26 & 16.77 & 2.82 & - \\
\hline SUS329J4L & 0.01 & 0.37 & 0.50 & 0.024 & 0.001 & 7.14 & 25.18 & 3.17 & 0.21
\end{tabular}

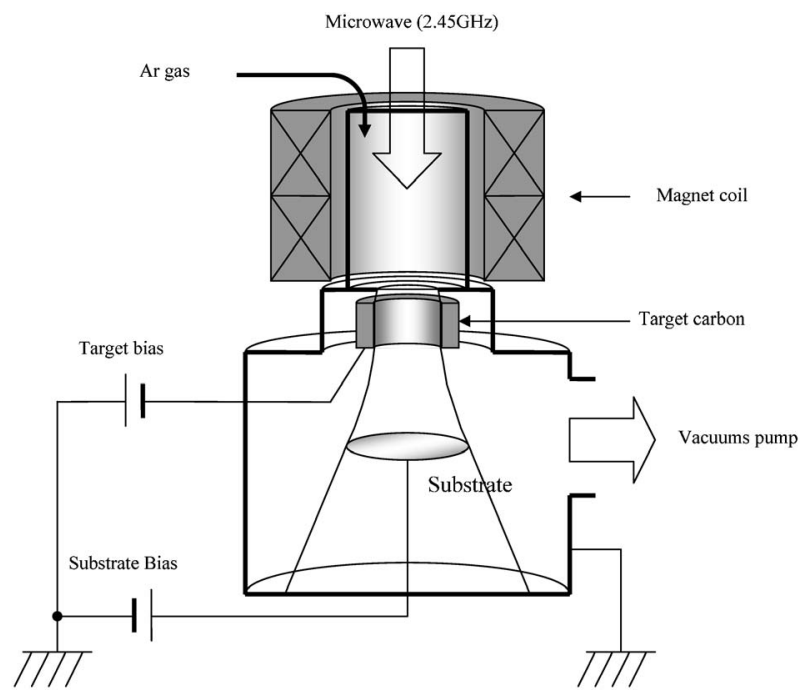

Fig. 1 Schematic drawing of the electron cyclotron resonance (ECR) plasma sputtering apparatus used for coating amorphous carbon.
プラズマ室から成膜室へ移動し基板であるステンレスに堆積 される.

本実験では油拡散ポンプで ECR スパッタリング装置内部 を $5 \times 10^{-3} \mathrm{~Pa}$ 以下の真空にした後, 高純度アルゴンガスを 導入し $1 \times 10^{-1} \mathrm{~Pa}$ とした. $\mathrm{ECR}$ パワーは $400 \mathrm{~W}$ ，基板バ イアスは $+20 \mathrm{~V}$ ，ターゲットバイアスは $-400 \mathrm{~V}$ ，成膜時間 は $7.2 \mathrm{ks}$ である。

\section{3 実験試料の表面分析}

実験試料の表面分析を堀場製作所製マーカス型高周波グ ロ一放電発光表面分析装置 (GD-OES; radio frequency glow discharge plasmas-optical emission spectrometer)を用いて 行った．GD-OES は Ar グロー放電領域内で試料表面を高周 波スパッタリングし，そのスパッタされる原子の Ar プラズ マ内に抢ける発光線を連続的に分光することにより皮膜の深 さ方向の元素分布を測定する手法である，本装置の特徵は， 皮膜の深さ方向の元素分布を高分解能かつ短時間で容易に得 ることが出来ることである。

\section{4 耐食性評価方法}

PEFC に用いられている電解質膜は無架橋のパーフルオロ スルフォン酸膜である. この電解質膜は水の存在下でポリマ 中のスルフォン酸 $\left(-\mathrm{SO}_{3} \mathrm{H}\right)$ がイオン化 $\left(-\mathrm{SO}_{3}^{-}\right)$して親水性 を示す．イオン化した分子が集合してポリマ中にクラスタが 生成し，このクラスタを通過してプロトンが伝導していく. したがって，この電解質膜のイオン伝導を維持するためには 水分量を高く保つことが必須である，そのため，PEFCに供 給されるガスは加湿されている．また，この電解質膜は強い 酸性を示すので, セパレータは $\mathrm{pH} 2 \sim 3$ の硫酸腐食環境に 曝されるといわれている，このような環境で金属が腐食され 電解質膜へ金属が溶出すると電解質膜は加速的に劣化すると いわれている. それを模擬して実験試料 $(\phi 20 \mathrm{~mm} \times t 2 \mathrm{~mm})$ を電解質膜と接触させて, $353 \mathrm{~K}$ の蒸留水中に $1.8 \times 10^{6} \mathrm{~s}$ 保 持した。電解質膜を硝酸溶液中に浸漬することで金属イオン を抽出し，その量をプラズマ発光分光法 (ICP)で分析した. 電解質膜中に溶出した金属量で耐食性を評価した.

\section{5 導電性評価方法}

PEFC ではセパレータはカーボンペーパーと接触する構造 となるのでそれを模擬して，実験試料 $(\phi 20 \mathrm{~mm} \times t 2 \mathrm{~mm})$ と カーボンペーパーとの接触抵抗を Fig. 2 に示す 4 端子法に よって測定した。 Solatron instruments 製 1280B ELECTROCHEMICAL MEASUREMENT UNIT を用いて印加す る電流密度を $-10 \mathrm{kA} / \mathrm{m}^{2}$ から $+10 \mathrm{kA} / \mathrm{m}^{2}$ の範囲で変化さ せ, 測定電圧と電流密度の勾配から電気抵抗を求めた. 尚, 押し付け圧力は $1 \mathrm{MPa}$ とした.

\section{6 発電特性評価}

燃料電池は，セルの内部抵抗によって，運転時に電圧降下 が起こる。内部抵抗は，1)セパレータやカーボンペー パー, 電解質膜/電極積層体などの導電性やそれらの接触に 由来するオーミック抵抗，2)酸素極側抢よび水素極側での 


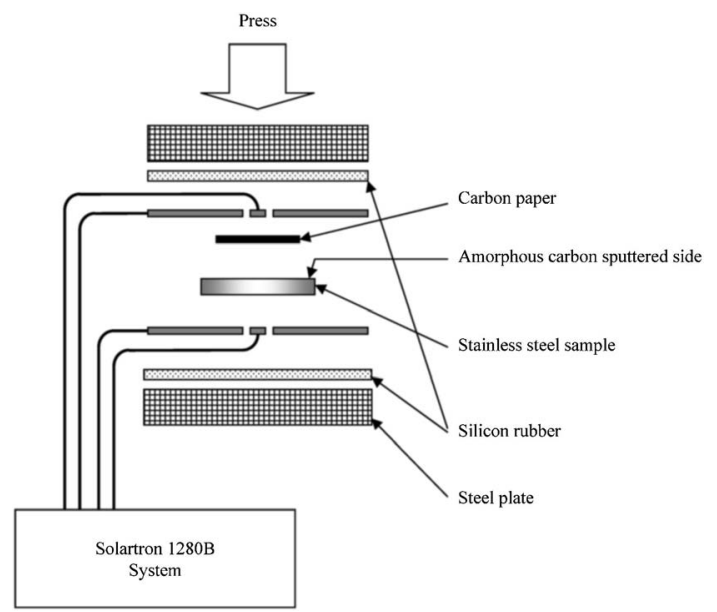

Fig. 2 Schematic drawing of system used for contact resistivity measurement.

電気化学反応に由来する反応抵抗，3)電極表面での酸素や 水素, 水などの物質移動に由来する拡散抵抗，などの成分に 分離することができる．高電流密度での燃料電池運転のため には，この内部抵抗の低減が重要となっているが，セパレー タの違いは, 主に1)のオーミック抵抗に影響すると思われ る.

燃料電池は電気化学反応によって発電を行っているので, その特性を調べるには出力される電圧と電流を測定する必要 がある，そこで，負荷電流を変化させながら負荷電流とセル 電圧の関係を測定し，電流一電圧特性を得た。

発電試験は, 電極面積が $5 \times 10^{-4} \mathrm{~m}^{2}$ のセパレータを組み 込んだ単セルを用いて行い，発電に際してセル温度を 343 $\mathrm{K}$, 水素抢よび空気の加湿温度を $333 \mathrm{~K}$ とした，ガス流量は 水素 $50 \mathrm{~mL} / \mathrm{min}$, 空気 $200 \mathrm{~mL} / \mathrm{min}$ とした。 また, 電池の 耐久性を評価するために，電流密度 $5 \mathrm{kA} / \mathrm{m}^{2}$ でセル電圧の 時間経過を測定した.

発電特性の向上抢よび劣化の要因分析にあたっては, 前述 のオーミック抵抗抢よび反応抵抗などを損失要素に分け定量 的に評価する必要がある。この損失を等価的にインピーダン スに置き換えて測定することで，電池内部の損失を解析する ことができる、インピーダンス法はセルに非常に微小な交流 信号を印加し, 電圧/電流の応答信号からセルのインピーダ ンスを測定する電気化学測定手法である.内部インピーダン スは簡易的に書くと Fig. 3(a)で示す等価回路のように表す ことができる，大まかに，オーミック抵抗 $R_{\mathrm{ohm}}$ と，電気二 重層容量 $\mathrm{Cd}$ に並列に存在する反応抵抗 $R_{\mathrm{c}}$ とに大別するこ とができる. Fig. 3(b)は Fig. 3(a)の回路のコールコールプ ロットの模式図である。この場合，コールコールプロットは 1 つの半円となる. 印加する周波数が高い時には, 電気二重 層容量 $\mathrm{Cd}$ で電流がバイパスされるため，オーミック抵抗 $R_{\mathrm{ohm}}$ の久が測定できる(Cole-Cole Plot 図の半円の左端). 印加する交流電流の周波数が十分低い時には，電気二重層容 量 $\mathrm{Cd}$ に電流が流れないため, オーミック抵抗 $R_{\mathrm{ohm}}$ と反応 抵抗 $R_{\mathrm{c}}$ の加算した抵抗值が現れる (Cole-Cole Plot 図の半円 の右端).

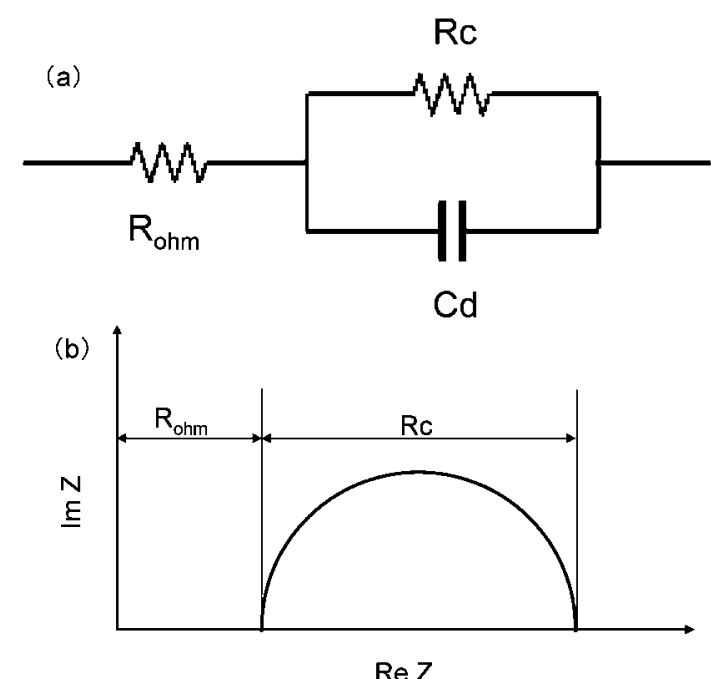

Fig. 3 Measurement of impedance: (a) Typical equivalent circuit of fuel cell, (b) Schematic drawing of Cole-Cole plot.

単セルの発電中のインピーダンスは Solatron instruments 製 1280B ELECTROCHEMICAL MEASUREMENT UNIT を用いて測定した.

\section{3. 結果および考察}

\section{1 実験試料の表面分析}

Fig. 4 に GD-OES による炭素を被覆していないステンレ 又表面からの深さ方向の元素分布分析結果を示す。(a)が SUS304，（b)が SUS316L，(c)が SUS329J4L である．ス テンレス表面は酸化皮膜で覆われて抢り，その酸化皮膜は最 外層が $\mathrm{Fe}$ を主とした $\mathrm{Fe}-\mathrm{Cr}$ 酸化物，その内部が $\mathrm{Cr}$ を主と した Fe-Cr 酸化物である. Fig. 5 に Fig. 4 の Cr 濃度分布を 比較したものを示す。 SUS329J4L の Cr 濃度が一番高い。 SUS304 と SUS316L の差は僅かであるが，SUS316L の酸 化皮膜中の $\mathrm{Cr}$ 濃度は SUS304 の酸化皮膜中の $\mathrm{Cr}$ 濃度より 高い，また，酸化皮膜の厚さは $2 \mathrm{~nm}$ 程度である．その酸化 皮膜の厚さを比較すると SUS316L が一番薄く，それに比べ て SUS304 および SUS329J4L は同程度に僅かに厚い。

Fig. 6 に GD-OES による炭素を被覆したステンレスの炭 素膜表面からの深さ方向の元素分布分析結果を示す（a）が SUS304，(b)が SUS316L，(c)が SUS329J4L である。炭 素膜はステンレス上に一様に成膜されており，炭素膜の厚さ は $60 \mathrm{~nm}$ 程度である。

Table 2 にバルク組成について ICP 分析結果および GDOES 分析結果を示す. ICP 分析結果と GD-OES 分析結果は ほぼ一致していると考えられる。

Fig. 7 に SUS316L 上に成膜した炭素膜の SEM 像を示 す. 炭素膜は緻密かつ平滑である.

\section{2 耐食性評価}

電解質膜中に溶出した金属量を ICP で分析した結果を Table 3 に示す。電解質膜への溶出金属量は Fe が最も多 く，炭素を被覆していない場合，SUS304 で 850 ppm， 

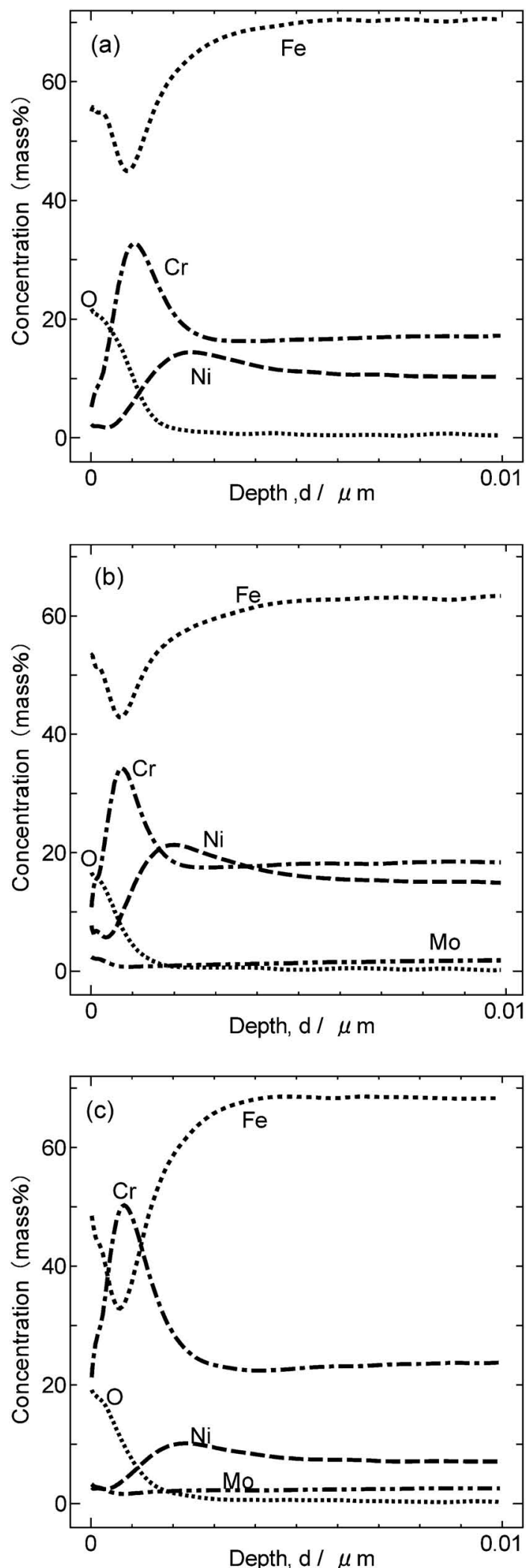

Fig. 4 GD-OES depth profiles on the stainless substrate without carbon coating: (a) SUS304, (b) SUS316L, (c) SUS329J4L.

SUS316L で 1500 ppm, SUS329J4L で 320 ppm であっ た。これに対し, 炭素を被覆すると Fe 溶出量は減少し SUS304 で 230 ppm, SUS316L で 100 ppm, SUS329J4L で $45 \mathrm{ppm}$ であった。 また， $\mathrm{Cr}, \mathrm{Ni}$ および $\mathrm{Mo}$ についても

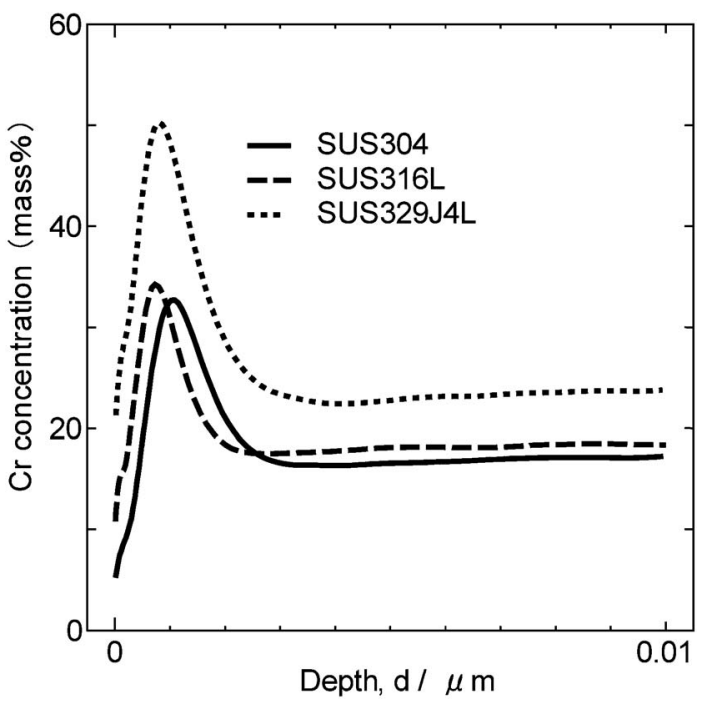

Fig. 5 GD-OES depth profiles of $\mathrm{Cr}$ on the stainless substrate without carbon coating.

炭素を被覆することにより，その溶出量は減少した。このよ うに炭素を被覆することにより耐食性が向上した。

電解質膜への溶出金属量は SUS329J4L が一番少ない。こ れは SUS329J4L では耐食性に優れる緻密な Cr リッチな酸 化皮膜がステンレス表面を覆っているためであると考えられ る.

炭素を被覆しない場合, 電解質膜への溶出金属量は, SUS304 では Fe: 850 ppm, Cr: 38 ppm, Ni: 44 ppm であるの に対し SUS316L では Fe: 1500 ppm, Cr: 150 ppm, Ni: 200 ppm であり, SUS304 に比べて SUS316L の方が多いことが 分かった．この理由としては，1）モリブデン添加は全面腐 食に対しては必ずしも有効とは言えないこと5)，2)不働態皮 膜の厚さは SUS316L より SUS304の方が厚いこと6)，3)ク ロム濃度が SUS304 に比べて SUS316L の方が少ないのでモ リブデンを含有していても耐食性が劣る場合があること7), などが考えられる.

\section{3 導電性評価}

Table 4 に 4 端子法によるステンレス試料とカーボンペー パーの接触抵抗測定結果を示す. 炭素を被覆しない場合の接 触抵抗は SUS304 で $103 \times 10^{-4} \mathrm{~m} \Omega \cdot \mathrm{m}^{2}, \mathrm{SUS} 316 \mathrm{~L}$ で $177 \times$ $10^{-4} \mathrm{~m} \Omega \cdot \mathrm{m}^{2}$, SUS329J4L で $194 \times 10^{-4} \mathrm{~m} \Omega \cdot \mathrm{m}^{2}$ であった. これに対し，炭素を被覆すると接触抵抗は $2 \sim 5 \times 10^{-4} \mathrm{~m} \Omega$. $\mathrm{m}^{2}$ となった。炭素を被覆することにより，ステンレスと カーボンペーパーの接触抵抗は 2 桁減少した.

\section{4 発電試験}

\subsection{1 $\mathrm{I}-\mathrm{V}$ 特性}

著者らは，既に市販ステンレス製セパレータを用いた単セ ルとカーボンセパレータを用いた単セルの I-V特性を報告 している4)が，本研究においてはセパレータのガス流路の断 面形状を幅と深さの比を $0.7: 1$ から $1: 1$ に見直すと共に SUS329J1 よりさらに耐食性に優れるSUS329J4L を取り上 

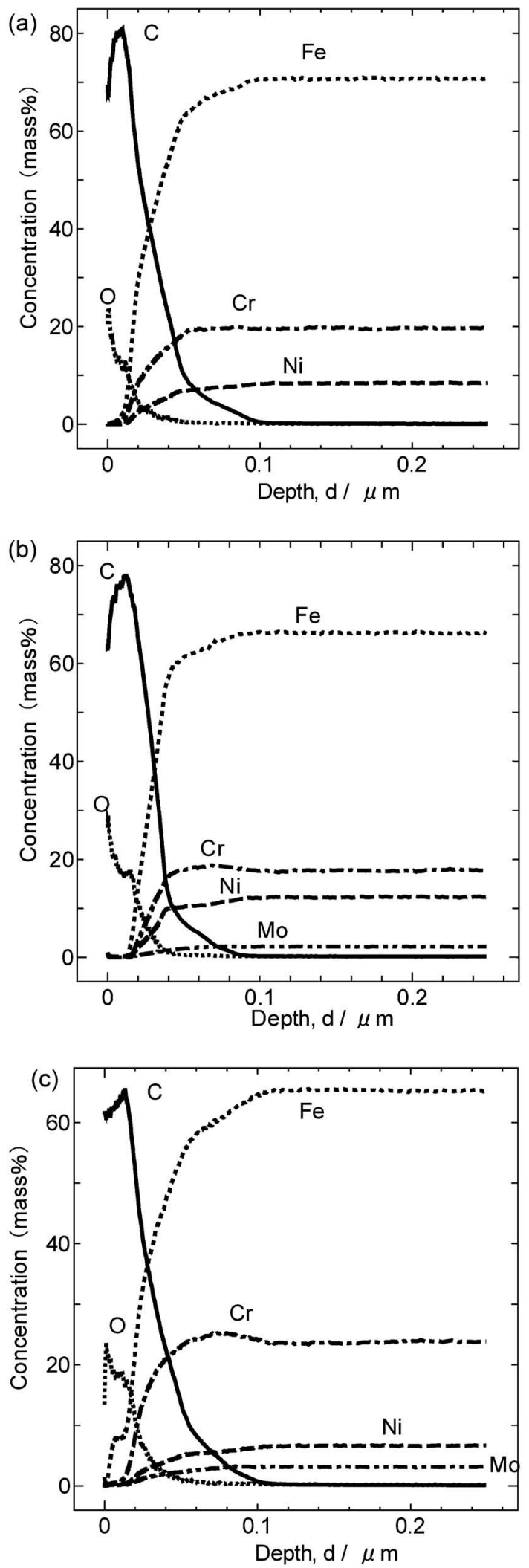

Fig. 6 GD-OES depth profiles on the stainless substrate with carbon coating: (a) SUS304, (b) SUS316L, (c) SUS329J4L.

\section{げて電池発電試験を行った.}

Fig. 8 にガス流路の断面形状を見直す前後のカーボンセパ レータを用いた単セルの I-V特性を示す.ガス流路の断面 形状を見直すことにより $\mathrm{I}-\mathrm{V}$ 特性が良くなった。
Table 2 Chemical composition by ICP and GD-OES of stainless steels for test specimen in mass\%.

\begin{tabular}{llrrr}
\hline Specimen & \multicolumn{1}{c}{ Analysis method } & $\mathrm{Ni}$ & $\mathrm{Cr}$ & $\mathrm{Mo}$ \\
\hline \multirow{3}{*}{ SUS304 } & ICP & 8.17 & 18.38 & - \\
\cline { 2 - 5 } & GD-OES without carbon coating & 10.33 & 17.24 & - \\
\cline { 2 - 5 } & GD-OES with carbon coating & 8.42 & 19.62 & - \\
\hline \multirow{3}{*}{ SUS316L } & ICP & 12.26 & 16.77 & 2.82 \\
\cline { 2 - 5 } & GD-OES without carbon coating & 14.89 & 18.37 & 1.81 \\
\cline { 2 - 5 } & GD-OES with carbon coating & 12.31 & 17.96 & 2.18 \\
\hline \multirow{3}{*}{ SUS329J4L } & ICP & 7.14 & 25.18 & 3.17 \\
\cline { 2 - 5 } & GD-OES without carbon coating & 7.06 & 23.78 & 2.59 \\
\cline { 2 - 5 } & GD-OES with carbon coating & 6.72 & 23.77 & 3.16 \\
\hline
\end{tabular}

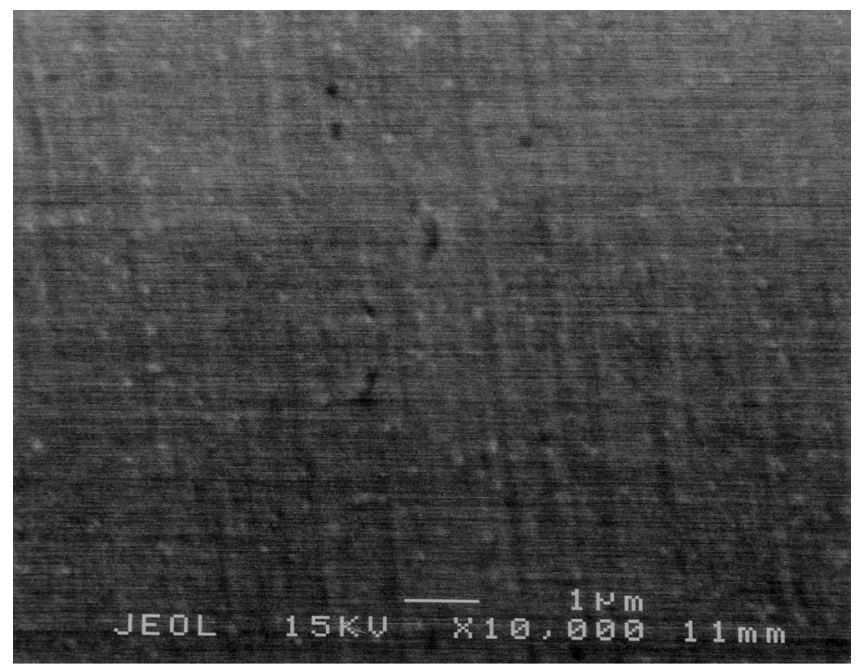

Fig. 7 SEM observation of an amorphous carbon film on a SUS316L substrate.

Table 3 Metal contents in ppm in membrane after immersion test in distilled water in air at $353 \mathrm{~K}$ for $1800 \mathrm{ks}$.

\begin{tabular}{clcccc}
\hline Specimen & & $\mathrm{Fe}$ & $\mathrm{Cr}$ & $\mathrm{Ni}$ & $\mathrm{Mo}$ \\
\hline \multirow{2}{*}{ SUS304 } & without carbon coating & 850 & 38 & 44 & - \\
\cline { 2 - 6 } & with carbon coating & 230 & 3.6 & 35 & - \\
\hline \multirow{2}{*}{ SUS316L } & without carbon coating & 1500 & 150 & 200 & 1.8 \\
\cline { 2 - 6 } & with carbon coating & 100 & 2.8 & 30 & 0.009 \\
\hline \multirow{2}{*}{ SUS329J4L } & without carbon coating & 320 & 14 & 24 & 0.051 \\
\cline { 2 - 6 } & with carbon coating & 45 & 1.3 & 9.0 & 0.008 \\
\hline
\end{tabular}

Fig. 9 (a)に炭素を被覆していない市販ステンレス製セパ レータを用いた単セルとカーボンセパレータを用いた単セル の $\mathrm{I}-\mathrm{V}$ 特性を示す. 後者の $\mathrm{I}-\mathrm{V}$ 特性に比べて前者の $\mathrm{I}-\mathrm{V}$ 特性は著しく悪い。 また, 前者の中ではSUS304 セパレー タを用いた単セルの I $-\mathrm{V}$ 特性が一番良く，それに比べて SUS316L および SUS329J4L セパレータを用いた単セルの $\mathrm{I}-\mathrm{V}$ 特性は同じように悪い. Table 4 に示した電流密度が 4 $\mathrm{kA} / \mathrm{m}^{2}$ におけるセル電圧を比較すると, SUS304: $0.631 \mathrm{~V}$, SUS316L: 0.577 V, SUS329J4L：0.582 V である. 4 端子法 
Table 4 Summary of resistivity and cell voltage.

\begin{tabular}{|c|c|c|c|c|c|c|}
\hline \multirow{3}{*}{ Specimen } & & \multicolumn{4}{|c|}{ Resistivity $\left(\mathrm{m} \Omega \cdot 10^{-4} \mathrm{~m}^{2}\right)$} & \multirow{3}{*}{$\begin{array}{c}\text { Cell voltage }(\mathrm{V}) \\
\text { at } 4 \mathrm{kA} / \mathrm{m}^{2}\end{array}$} \\
\hline & & \multirow{2}{*}{ with four-point probe } & \multicolumn{3}{|c|}{ with impedance meter at $4 \mathrm{kA} / \mathrm{m}^{2}$} & \\
\hline & & & $R_{\mathrm{ohm}}$ & $R_{\mathrm{c}}$ & $R_{\mathrm{ohm}}+R_{\mathrm{c}}$ & \\
\hline \multirow{2}{*}{ SUS304 } & without carbon coating & 103 & 210 & 525 & 735 & 0.631 \\
\hline & with carbon coating & 2 & 99 & 566 & 665 & 0.695 \\
\hline SUS316L & without carbon coating & 177 & 315 & 535 & 850 & 0.577 \\
\hline \multirow{2}{*}{ SUS329J4L } & without carbon coating & 194 & 355 & 495 & 850 & 0.582 \\
\hline & with carbon coating & 2 & 94 & 486 & 580 & 0.706 \\
\hline Carbon & - & - & 90 & 420 & 510 & 0.728 \\
\hline
\end{tabular}

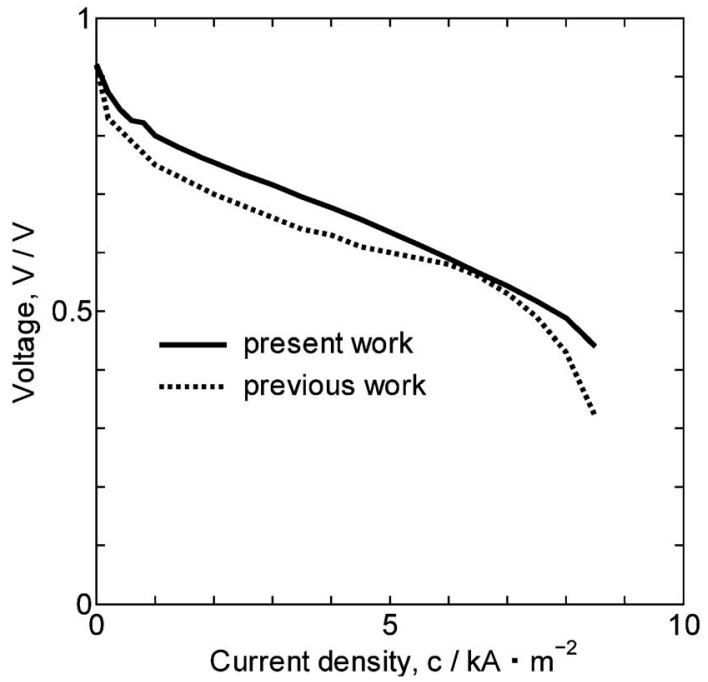

Fig. 8 Polarization performances of PEFC single cells using the carbon separator.

による接触抵抗を比較すると SUS304: $103 \times 10^{-4} \mathrm{~m} \Omega \cdot \mathrm{m}^{2}$, SUS316L: $177 \times 10^{-4} \mathrm{~m} \Omega \cdot \mathrm{m}^{2}$, SUS329J4L: $194 \times 10^{-4} \mathrm{~m} \Omega$. $\mathrm{m}^{2}$ である。セ電圧を高い方から並べると SUS304> SUS329L4L $\fallingdotseq S U S 316 L$ となり, 接触抵抗を小さい方から 並べるとSUS304 $<$ SUS316L $\fallingdotseq S U S 329 J 4 L$ となる，接触抵 抗の小さい方がセル電圧が高くなる傾向にある.

Fig. 9 (b)には，炭素を被覆した市販ステンレス製セパ レータを用いた単セルとカーボンセパレータを用いた単セル の I-V特性を示す．炭素を被覆しなかった場合に比べて I $\mathrm{V}$ 特性は大幅に改善し，炭素を被覆した市販ステンレス製セ パレータを用いた単セルの I-V特性はカーボンセパレータ を用いた単セルのI-V特性と同等になった．Table 4 に示 すように炭素を被覆しない場合の接触抵抗は SUS304 で $103 \times 10^{-4} \mathrm{~m} \Omega \cdot \mathrm{m}^{2}, \quad$ SUS316L で $177 \times 10^{-4} \mathrm{~m} \Omega \cdot \mathrm{m}^{2}$, SUS329J4L で $194 \times 10^{-4} \mathrm{~m} \Omega \cdot \mathrm{m}^{2}$ であった。これに対し， 炭素を被覆すると接触抵抗は $2 \sim 5 \times 10^{-4} \mathrm{~m} \Omega \cdot \mathrm{m}^{2}$ となっ た．このことから電気抵抗の高い酸化皮膜が存在しても炭素 を被覆することによって電気が流れるようになったためカー ボンセパレータと同等の I-V特性を示したと考えられる.

\section{4 .2 インピーダンス測定}

Fig. 10 に炭素を被覆していないステンレス製セパレータ
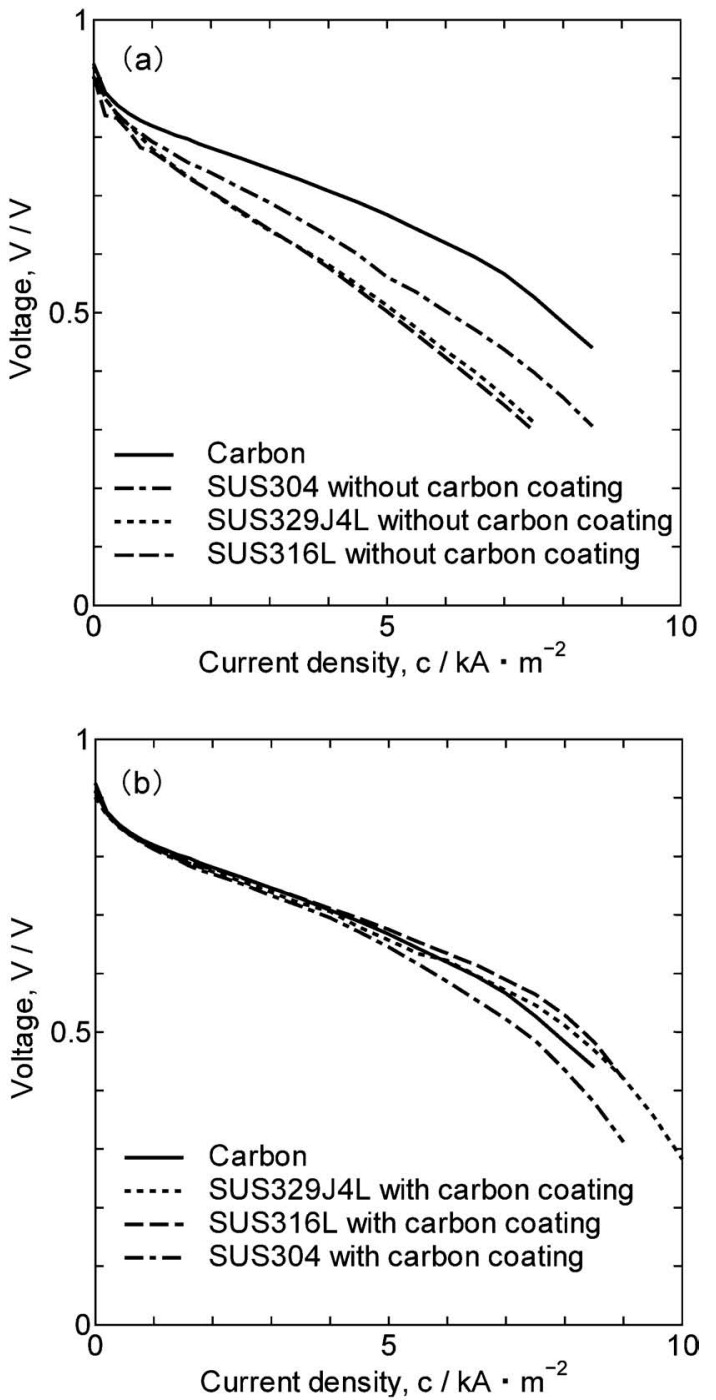

Fig. 9 Polarization performances of PEFC single cells using the stainless separators (a) without the carbon coating, (b) with the carbon coating, compared with the conventional carbon separator.

を用いた単セルの Cole-Cole plotを，また，Table 4 にイン ピーダンス測定結果を示す．SUS304においては $R_{\mathrm{ohm}} ： 210$ $\times 10^{-4} \mathrm{~m} \Omega \cdot \mathrm{m}^{2}, R_{\mathrm{c}}: 525 \times 10^{-4} \mathrm{~m} \Omega \cdot \mathrm{m}^{2}$, SUS316L に扔いて は $R_{\text {ohm }}: \quad 315 \times 10^{-4} \mathrm{~m} \Omega \cdot \mathrm{m}^{2}, \quad R_{\mathrm{c}}: \quad 535 \times 10^{-4} \mathrm{~m} \Omega \cdot \mathrm{m}^{2}$, SUS329J4L に抢いては $R_{\mathrm{ohm}}: 355 \times 10^{-4} \mathrm{~m} \Omega \cdot \mathrm{m}^{2}, R_{\mathrm{c}}: 495 \times$ 


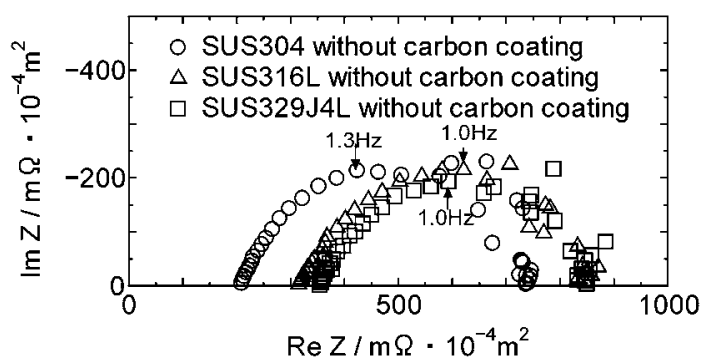

Fig. 10 Cole-Cole plots during operation at $4 \mathrm{kA} / \mathrm{m}^{2}$ for PEFC single cells using the stainless separators without the carbon coating.
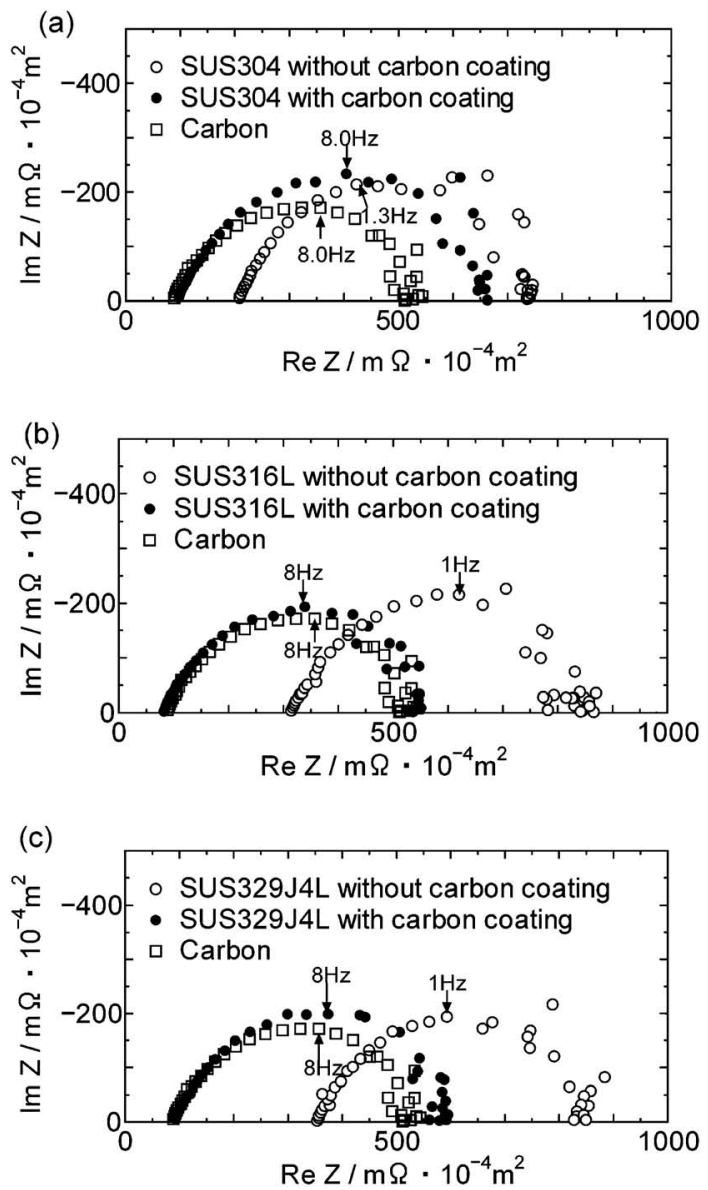

Fig. 11 Cole-Cole plots during operation at $4 \mathrm{kA} / \mathrm{m}^{2}$ for PEFC single cells using the stainless separators: (a) SUS304, (b) SUS316L, (c) SUS329J4L without and with the carbon coating, compared with the conventional carbon separator.

$10^{-4} \mathrm{~m} \Omega \cdot \mathrm{m}^{2}$ である. 反応抵抗 $\left(R_{\mathrm{c}}\right)$ の差に比べてオーミック 抵抗 $\left(R_{\mathrm{ohm}}\right)$ の差が明らかに大きい。オーミック抵抗の差が $\mathrm{I}-\mathrm{V}$ 特性の差の原因である.

Fig. 11 に炭素を被覆したステンレス製セパレータを用い た単セルの特性を炭素を被覆していないステンレス製セパ レータの特性およびカーボンセパレータを用いた単セルの特 性と比較した Cole-Cole plotを示す。（a）が SUS304，(b)が SUS316L，(c)が SUS329J4L の場合である. Table 4 に示 したオーミック抵抗 $\left(R_{\mathrm{ohm}}\right)$ について炭素を被覆しない場合 と被覆した場合とを比較すると, SUS304 では $210 \times 10^{-4}$

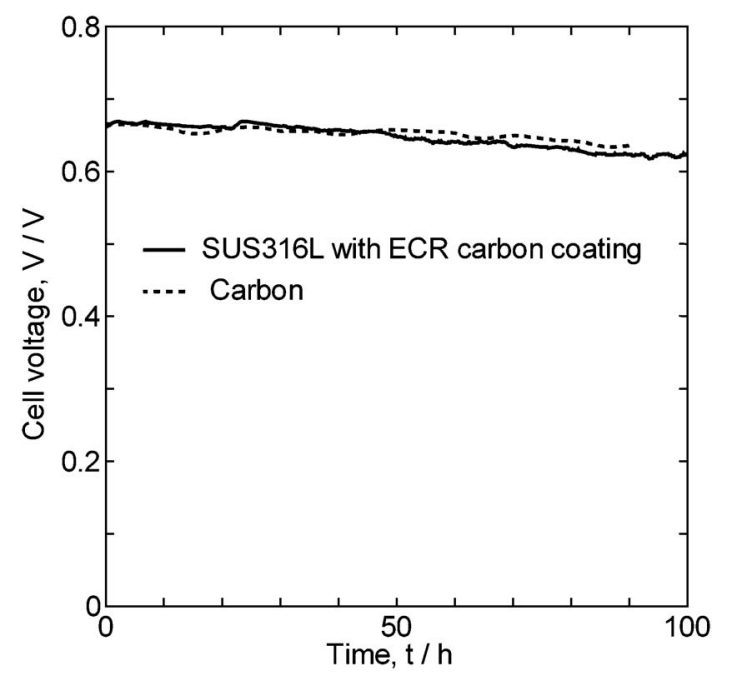

Fig. 12 Durability of PEFC single cell using the SUS316L separator with the carbon coating, compared with the conventional carbon separator.

$\mathrm{m} \Omega \cdot \mathrm{m}^{2}$ が $99 \times 10^{-4} \mathrm{~m} \Omega \cdot \mathrm{m}^{2}$ に, SUS316L では $315 \times 10^{-4}$ $\mathrm{m} \Omega \cdot \mathrm{m}^{2}$ が $83 \times 10^{-4} \mathrm{~m} \Omega \cdot \mathrm{m}^{2}$ に, SUS329J4L では $355 \times 10^{-4}$ $\mathrm{m} \Omega \cdot \mathrm{m}^{2}$ が $94 \times 10^{-4} \mathrm{~m} \Omega \cdot \mathrm{m}^{2}$ に減少した. 一方, 反応抵抗 $\left(R_{\mathrm{c}}\right)$ について炭素を被覆しない場合と被覆した場合とを比 較すると, SUS304 では $525 \times 10^{-4} \mathrm{~m} \Omega \cdot \mathrm{m}^{2}$ と $566 \times 10^{-4}$ $\mathrm{m} \Omega \cdot \mathrm{m}^{2}, \quad \mathrm{SUS} 316 \mathrm{~L}$ では $535 \times 10^{-4} \mathrm{~m} \Omega \cdot \mathrm{m}^{2}$ と $447 \times 10^{-4}$ $\mathrm{m} \Omega \cdot \mathrm{m}^{2}, \quad \mathrm{SUS} 329 \mathrm{~J} 4 \mathrm{~L}$ では $495 \times 10^{-4} \mathrm{~m} \Omega \cdot \mathrm{m}^{2}$ と $486 \times 10^{-4}$ $\mathrm{m} \Omega \cdot \mathrm{m}^{2}$ であり, 反応抵抗 $\left(R_{\mathrm{c}}\right)$ はあまり変化していない。こ のように，いずれのステンレスに㧤いも炭素を被覆するこ とによりオーミック抵抗が著しく減少するので I-V特性が 著しく改善された.

\subsection{3 連続発電試験結果}

炭素を被覆した SUS316L セパレータを用いた単セルの一 定負荷 $\left(5 \mathrm{kA} / \mathrm{m}^{2}\right)$ に抢ける連続発電試験結果を Fig. 12 に示 す，炭素を被覆した SUS316L セパレータを用いた単セルは カーボンセパレータを用いた単セルと同等のセル電圧推移を 示す.

\section{4. 結言}

市販ステンレスおよび炭素を被覆した市販ステンレスを用 い, 導電性評価, 耐食性評価抢よび単セルの発電試験を行っ た結果，炭素を被覆した市販ステンレスを用いた単セルは カーボンを用いた単セルと同等の I-V特性を示した.

本研究結果のまとめを以下に示す.

(1) 炭素を被覆することにより，ステンレスとカーボン ペーパーの接触抵抗は 2 桁減少した.

（2）炭素を被覆することにより耐食性は著しく向上した.

（3）SUS316L および SUS329J4L に炭素を被覆した金属 セパレータを用いた単セルは, 現状使用されているカーボン セパレータを用いた単セルと同等の I-V特性を示した。

（4）金属セパレータの選定にあたっては，耐食性を十分に 吟味することが重要である。 


\section{文献}

1) Z. Ogumi: JSMS Committee on Corrosion and Protection 46 (2007) $1-7$.

2) Y. Tarutani: JSMS Committee on Corrosion and Protection 46 (2007) $20-27$.

3) H. Yamaguchi, K. Yamaga and K. Takahashi: The 45th Battery
Symposium in Japan (2004) 104-105

4) M. Ueda, M. Hashimoto, Y. Mori, S. Tanase, Y. Aoi, M. Iwasa and T. Sakai: KURIMOTO TECHNICAL REPORT $\mathbf{5 5}$ (2006) 26.

5) S. Ogura, K. Sugimoto and Y. Sawada: Corros. Sci. 16(1976) 323-337.

6) K. Varga, P. Baradlai, W. O. Bernard, G. Myburg, P. Halmos and J. H. Potgieter: Electrochim. Acta. 42 (1997) 25-35.

7) K. Sugimoto and Y. Sawada: Corros. Sci. 17(1977) 425-445. 